GLOBAL JOURNAL OF PURE AND APPLIED SCIENCES VOL. 21, 2015: 181-172

COPYRIGHTC BACHUDO SCIENCE CO. LTD PRINTED IN NIGERIA ISSN 1118-0579 www.globaljournalseries.com, Email: info@globaljournalseries.com

\title{
PERCEPTION AND ATTITUDES OF PARENTS TOWARDS TEENAGE PREGNANCY IN A RURAL COMMUNITY OF CROSS RIVER STATE, NIGERIA
}

DORIS O. MGBOKWERE, EKPOANWAN E. ESIENUMOH AND DAVID A. UYANA

(Received 15 May 2015; Revision Accepted 26 June 2015)

\begin{abstract}
Teenage pregnancy is a social menace and common public health problem. It is detrimental to both mother and child because teenage mother is not physically, psychologically and economically ready to bear a child. This phenomenon has multiple adverse consequences on maternal health, child health and overall wellbeing of the society. This study investigated the perception and attitudes of parents towards teenage pregnancy in a rural community in Akpabuyo Local Government Area. The objectives included: to determine parents' perception on teenage pregnancy and to determine parents' attitudes towards teenage pregnancy. A null hypothesis was stated to test the association between demographic characteristics of parents and their attitude towards teenage pregnancy. Descriptive survey was used and data were collected through self administered questionnaire to a sample of 309 respondents selected through purposive sampling. SPSS version 21.0 was utilized for data analysis. The findings included that $93 \%$ of parents claimed that a pregnant teenager outside wedlock is a social deviant and $85.8 \%$ said teenage pregnancy is a sign of parental failure. Their attitudinal behaviour showed that the affected girl would be sent away from the family $(32.7 \%)$, parents would stop her education (49.8\%) and that the girl would be abandoned to the man/boy responsible for the pregnancy. Sociodemographic characteristics of parents depicted by gender, education and religion were significantly associated with the attitudes of parents towards teenage pregnancy. Conclusion was made that gaps exist in parental perception and attitudes towards teenage pregnant girls. Therefore, it is recommended that parents should reappraise and strengthen their obligations towards their adolescent/teenage daughters to enable them achieve their full potentials through prevention of teenage pregnancies.
\end{abstract}

KEYWORDS: Teenage pregnancy, parental perceptions, parental attitudes, adolescent pregnancy

\section{INTRODUCTION}

Teenage pregnancy is a common occurrence globally. World Health Organisation (WHO) statistics show that about sixteen million adolescents aged 15-19 years give birth each year and most of these births occur in the developing countries (World Health Organization, 2014). The trend seems to be increasing. Teenage pregnancy accounted for 40 percent of maternal deaths in Sierra Leone where early marriage is supported by traditional practice (Interpress Service, 2011). Some authors have defined teenage pregnancy as that which occurs in the young girl between the age of 13 and 19 years when the reproductive organs and system are not fully developed (Spencer, 2011). This phenomenon is described as a social problem in which adult practices and functions such as sexual intercourse, reproduction and mothering are undertaken by a person who owing to her age and developmental status is not yet an adult (Macleod, 2011).

Teenage pregnancy constitutes a public health problem and has been identified as a problem for teenagers, the families and society at large. It is a major contemporary social problem confronting countries in the world. In developed and developing countries, teenage pregnancy continues to receive increasing attention. This is because of the early age at which adolescents engage in sexual activity with the result of unplanned pregnancy and the likely complications (Marnach, Forrest and Goldman, 2013). Such pregnancies are risks to both mother and baby (National Population Commission \& ICF, 2013). Risks to babies include prematurity, low birth weight and birth injuries. The mother may suffer morbidities such as obstructed labour, obstetric fistula and eclampsia (Marnach et al., 2013). Also, early motherhood results with the adolescents lacking adequate information, education and communication on reproductive health matters.

Some social and psychological problems are also associated with teenage pregnancy such as dropping out of school, social discrimination and stigmatization. The pregnant teenager might become depressed and thus, at risk of suicide (Marnach et al., 2013; Telford, 2013).

Many factors have been associated with the occurrence of teenage pregnancy. These include poor parental supervision as a result of broken homes and inadequate or absence of contraceptives (Meddinus \& Johnson, 2007); exposure to pornographic films and lack of sex education (Mitchel, 2007). In response to the problem of teenage pregnancy, the World Health Organisation in 2011 adopted a resolution which urged

Doris O. Mgbokwere, Department of Nursing Science, University of Calabar, Calabar, Nigeria.

Ekpoanwan E. Esienumoh, Department of Nursing Science, University of Calabar, Calabar, Nigeria.

David A. Uyana, Department of Mathematics and Statistics, Cross River State University of Technology, Calabar, Calabar, Nigeria. 
member States to accelerate actions to improve the health of young people through the following measures: i) reviewing and revising policies to protect young people from early child-bearing; ii) providing access to contraception and reproductive health care services and iii) promoting access to accurate information on sexual and reproductive health (WHO, 2014).

\section{Statement of problem}

Health and social problems are associated with teenage pregnancy. To avert these, strategies previously mentioned were resolved by the WHO (2014) aimed at improving the reproductive health of young people including adolescents. Consequent on these strategies, interventions by public and private organizations have been undertaken to reduce the problem. Despite these interventions which include access to reproductive health services, it is observed globally that teenage pregnancy still remains a public health problem (Salaman, 2010). In Nigeria, statistics from the National Population Commission (NPC) shows that the proportion of teenage pregnancy has remained at $23 \%$ between 2008 and 2013 (NPC \& ICF, 2013; NPC \& ICF, 2009). Although in Nigeria, the highest proportions are found in the North Western (36\%) and North Eastern (34\%) parts of the country, in the south with relatively lower proportion, the rate of teenage pregnancy is highest in Cross River State (17\%) as compared with other southern states in the southern geopolitical zone (NPC \& ICF, 2013). It was further documented that the rate of teenage pregnancy is about $32 \%$ in the rural areas and $10 \%$ in the urban areas. This study setting is a rural community and many teenage girls are already mothers. In view of their roles, parents are expected to be actively involved in the process of prevention of teenage pregnancy through supervision and counselling of their children/wards (Silk \& Romero, 2014). To the best of our knowledge, the perspectives of parents on teenage pregnancy in the study area have not been explored. Based on these gaps, the researchers decided to study the perception and attitudes of parents towards teenage pregnancy in this Community.

\section{AIM OF STUDY}

The main aim of this study was to investigate the perception and attitudes of parents towards teenage pregnancy in a rural community in Akpabuyo Local Government Area, Cross River State.

\section{Specific objectives}

The specific objectives of this study were to:

- assess the perception of parents on teenage pregnancy in this community.

- determine the attitudes of parents towards teenage pregnancy

- determine the relationship between the sociodemographic attributes of parents and their attitudes towards teenage pregnancy.

\section{Research hypotheses}

There is no significant relationship between sociodemographic attributes of parents and their attitudes towards teenage pregnancy.

\section{Significance of study}

Through this study data will be generated on the perception and attitudes of parents towards teenage pregnancy in this community. In addition, the findings of this research will stimulate further studies on teenage pregnancy. The findings are expected to influence policy on teenage/adolescent reproductive health as well as provide information on this subject to parents of adolescent girls.

\section{LITERATURE REVIEW}

\section{Perception of teenage pregnancy by parents}

The news of teenage daughter's pregnancy is unpleasant to parents. Some authors found that mothers described their feelings resulting from the discovery of the pregnancy of their adolescent daughters as devastating. The news was difficult to believe, welcome or accept. Many demonstrated that they had not liked receiving the news. Some added that it took them a long time to accept the reality. Some other mothers described the situation as a fearful and shocking one that caused discontentment (Fernandes et al., 2012; Gilbert, 2011). Some fathers were also equally disappointed and expressed their difficulty in accepting the pregnancy and the arrival of a new baby while some acknowledged it as a mistake (Fernandes et al., 2012).

While some parents would grief and worry about the future of such girls (Nava, 2010), some other parents would feel a sense of guilt at the thought that they had failed in their responsibility and could have done more to protect their child from this predicament. On the one hand, some parents felt embarrassed by their teen's pregnancy and worried about how family, friends and neighbours would react. This position was consistent with that of Nava (2012) who found that such teen's parents were gossiped about and the affected teens seen as bad influence. On the other hand, others were happy about the news of a soon to-be grandmother especially if the teen is older and in a mature relationship. They may also expect a great deal of pleasure from their new grandchild (Health Direct, 2012).

A study showed that mothers of pregnant adolescents, who had also experienced adolescent pregnancy were more understanding of the problems experienced by their daughters. Such mothers also expressed that they accept the situation and give their daughters the required support (Health Direct, 2012).

It has been identified that pregnancy in adolescence brings significant changes in behaviour of families, with the mother figure being highlighted as a source of support and maintenance of the family structure. The importance of emotional support, affection and information throughout the gestational process has also been recognised. These factors are considered to be decisive for the adjustment to pregnancy and the maternal role by the affected adolescent (Fernandes et al., 2010).

\section{Attitude of parents towards teenage pregnancy}

In a study, it was observed that despite the mothers' initial discontent, criticisms and sadness, some mothers accepted the fact, still exercised their roles, 
accompanying and guiding their adolescent daughters during this new phase. They provided support for adolescent to care for their child both financial aspects and with household chores (Fernandes et al., 2012; Coster, 2013). It was further noted that many accept the situation and overcame the initial conflict. Overwhelming as the situation may be, Coster (2013), recommended that affected parents should keep their calm; try to understand how the girl is feeling and try to deal with the situation in a positive manner that would result in a favourable outcome for the teenage mother. It is also documented that contrarily, some fathers would not accept such shame of adolescent daughter's pregnancy. They broke contact with their daughters and stopped telephoning and visiting those (Fernandes et al., 2012). In another circumstance, though there was an initial resentment, family involvement occurred in a positive manner after the birth of the baby (Fernandes et al., 2012).

\section{METHODS}

\section{Research design}

Descriptive survey design was used for this study to find out how parents perceive teenage pregnancy as well as what their attitudes are towards this phenomenon.

\section{Research setting}

The setting for the study was a rural community in Akpabuyo Local Government Area. It is a rural community with the population of about 7,000 people. The major occupation of the people are farming and trading. The community has a Health Centre popularly referred to as 'Maternity' by members of the community and its environs. The Health Centre offers primary health care services to members of the community and its environs.

\section{Research population}

The target population for this study consisted of the inclusion criteria of both men and women from age 35 years and above, who are parents and are residents in this community in Akpabuyo Local Government Area. This was 1,928 (National Population Commission, 2014).

\section{Sample and sampling technique}

A sample size of 331 parents within the inclusion criteria were selected for the study, representing $17 \%$ of the total population. Yamane formula (1967) was used to determine the sample size.

Purposive sampling was adopted to enable the recruitment of subjects with the required characteristics for the study.

\section{Instrument for data collection}

The instrument for data collection was a questionnaire comprised of four sections thus:
Section A: A generated data on the sociodemographic variables of parents.

Section B: Consisted of questions on parents' perception of teenage pregnancy.

Section C: Attitude of parents towards teenage pregnancy.

\section{Validity of instrument}

To ensure validity of the instrument, the researchers constructed the instrument to reflect the variables under investigation as indicated in the specific objectives.

\section{Reliability of instrument}

In order to assess reliability of the instrument, a test re-test method of reliability was adopted. The instrument was administered to 30 parents within the targeted age range of 35 years and above in a neighbouring community in Akpabuyo Local Government Area, prior to study. After an interval of one week, the same instrument was re-administered to the same persons and a reliability co-efficient value of 0.90 was obtained. This was considered high enough for the study.

\section{Method of data collection}

The questionnaire was administered directly to the literate respondents using the face to face method by the researchers and an assistant. The same questionnaire was used as structured interview for respondents who could not read English following reading and interpretation of the questions to them by the research assistant.

\section{Method of data analysis}

Data were analysed using SPSS version 21.0. The hypotheses were tested for significance at 0.05 level using t-test and one-way Analysis of Variance.

\section{Ethical consideration}

Approval for the study was obtained from Chairman of Akpabuyo Local Government Area as well as the Community Leader. Consent was also obtained from the individual respondents prior to administration of the questionnaire. The respondents were also assured of confidentiality of the data and anonymity.

\section{RESULTS}

The data were analysed using frequency counts, percentages, correlational t-tests, and one-way Analysis of Variance, using SPSS version 21.0. All decisions were taken at 0.05 level of significance. The content was organized under the following headings:

\section{Demographic analysis of samples}

The data for this study was collected from 309 respondents. The demographic description of the sample was done using frequency counts and percentages. Table 1 is a summary of the results. 
Table 1: Demographic description of study sample $(n=309)$

\begin{tabular}{|l|l|l|l|}
\hline Variable & Category & Frequency & \% \\
\hline Gender & Male & 117 & 37.9 \\
& Female & 192 & 62.1 \\
& Total & $\mathbf{3 0 9}$ & $\mathbf{1 0 0 . 0}$ \\
\hline Age & $35-39$ & 86 & 27.8 \\
& $40-44$ & 69 & 22.3 \\
& $45-49$ & 39 & 12.6 \\
& $50-54$ & 30 & 9.7 \\
& $55-59$ & 50 & 16.2 \\
& $60-64$ & 27 & 8.7 \\
& $65 \&$ above & 8 & 2.6 \\
& Total & $\mathbf{3 0 9}$ & $\mathbf{1 0 0 . 0}$ \\
\hline Religion & Christianity & 255 & 82.5 \\
& Muslim & 23 & 7.4 \\
& Traditional & 31 & 10.0 \\
& Total & $\mathbf{3 0 9}$ & \\
& Single & 50 & $\mathbf{1 0 0 . 0}$ \\
\hline Marital status & Married & 209 & 16.2 \\
& Divorced/separated & 25 & 67.6 \\
& Widowed & 25 & 8.1 \\
& Total & $\mathbf{3 0 9}$ & 8.1 \\
& & & $\mathbf{1 0 0 . 0}$ \\
\hline Educational level & Primary & 69 & \\
& Secondary & 142 & 22.3 \\
& Tertiary & 98 & 46.0 \\
& Total & 31.7 \\
& Efik & $\mathbf{3 0 9}$ & \\
& Ibibio & $\mathbf{2 1 1}$ & $\mathbf{1 0 0 . 0}$ \\
\hline Tribe & Others & 9 & 28.3 \\
& Total & $\mathbf{3 0 9}$ & 2.9 \\
& & & $\mathbf{1 0 0 . 0}$ \\
\hline
\end{tabular}

From Table 1, there were 117 (37.9\%) male respondents and $192(62.1 \%)$ female respondents. The age distribution showed that $86(27.8 \%)$ of them were in the age range 35-39years, $69(22.3 \%)$ in the range $40-$ 44 years, $39(12.6 \%)$ in the range $45-49$ years and 30 $(9.6 \%)$ in the age group $50-54$ years. Of the remaining, $50(16.2 \%)$ were between 55 and 59 years $29(8.7 \%)$ within 60-64 years and $8(2.6 \%)$ were 65 years or above.
Majority, 225 (82.5\%) were Christians, 23 (7.4\%) were Muslims and $31(10.0 \%)$ were traditional worshippers. The distribution also showed that majority $209(67.6 \%)$ were married, $50(16.2 \%)$ single, and 50 $(16.2 \%)$ were either divorced or widowed. Educational status of the subjects showed that $69(22.3 \%)$ had primary education, $142(46.0 \%)$ secondary and 98 $(31.7 \%)$ had tertiary education. Majority of the subjects were Efiks, 211 (68.3\%), 89 (28.8\%) were Ibibios while $9(2.9 \%)$ were from some other tribes.

Table 2: Perception of parents about teenage pregnancy $(n=309)$

\begin{tabular}{|l|l|l|l|}
\hline Items & Agreed & Disagreed & Total \\
\hline $\begin{array}{l}\text { A teenage pregnant girl is a } \\
\text { deviant }\end{array}$ & $288(93 \%)$ & $21(7 \%)$ & $309(100 \%)$ \\
\hline $\begin{array}{l}\text { A teenage pregnant girl does not } \\
\text { have a future }\end{array}$ & $259(84 \%)$ & $50(16 \%)$ & $309(100 \%)$ \\
\hline $\begin{array}{l}\text { Teenage pregnancy makes } \\
\text { parents devastated }\end{array}$ & $265(85.8 \%)$ & $44(14.2 \%)$ & $309(100 \%)$ \\
\hline $\begin{array}{l}\text { Teenage pregnancy means that } \\
\text { parents have failed }\end{array}$ & $264(85 \%)$ & $35(15 \%)$ & $309(100 \%)$ \\
\hline $\begin{array}{l}\text { Teenage pregnancy results in } \\
\text { stigmatization }\end{array}$ & $276(89 \%)$ & $33(11 \%)$ & $309(100 \%)$ \\
\hline $\begin{array}{l}\text { Teenage pregnancy is the result } \\
\text { of western education }\end{array}$ & $217(70.2 \%)$ & $92(29.8 \%)$ & \\
\hline
\end{tabular}


Perception of parents about teenage pregnancy

Parents' perception of teenage pregnancy is shown in Table 2. Some of them 288(93\%) said that teenage pregnant girls are deviants, 259(84\%) said that such girls do not have future while 265(85.8\%) expressed that they would be devastated at teenage pregnancy. Additionally, 264(85\%) saw this as a mark that the parent of such a girl is a failure; $276(89 \%)$ expressed that a teenage pregnancy is a stigma and $217(90.2 \%)$ said that this condition is the effect of Western education.

In Table 3, the attitudes of parents towards teenage pregnancy are presented.

Table 3: Attitudes of parents towards teenage pregnant girl $(n=309)$

\begin{tabular}{|l|l|l|l|}
\hline Variables & Agreed & Disagreed & Total \\
\hline $\begin{array}{l}\text { Drive girl away from the family in } \\
\text { anger }\end{array}$ & $101(32.7 \%)$ & $208(67.3 \%)$ & $309(100 \%)$ \\
\hline Stop her schooling & $154(49.8 \%)$ & $155(50.2 \%)$ & $309(100 \%)$ \\
\hline Give her out in early marriage & $194(62.8 \%)$ & $115(37.2 \%)$ & $309(100 \%)$ \\
\hline Abort pregnancy & $49(15.92 \%)$ & $260(84.1 \%$ & $309(100 \%)$ \\
\hline Send to mission home for care & $215(69.6 \%)$ & $94(30.4 \%$ & $309(100 \%)$ \\
\hline Support girl to have the baby & $178(57.6 \%)$ & $131(42.4 \%)$ & $309(100 \%)$ \\
\hline $\begin{array}{l}\text { Force the man/boy responsible } \\
\text { for the pregnancy to accept } \\
\text { responsibility of her care }\end{array}$ & $260(84 \%)$ & $49(16 \%)$ & $309(100 \%)$ \\
\hline
\end{tabular}

\section{Attitudes of parents towards teenage pregnancy}

Parents presented various attitudinal dispositions towards teenage pregnancy. These included: driving the girl away in anger from the family $101(32.7 \%)$. On the other hand, 208(67.3\%) parents were in favour of keeping such girls in the family. Concerning the education of the girl, 154(49.8\%) would stop her from schooling and 194(62.8\%) parents said they would give out the girl in early marriage irrespective of her age. A few parents $49(15.9 \%)$ would get the pregnancy aborted but $260(84.1 \%)$ would encourage the pregnancy to be kept.

Some parents $215(69.6 \%)$ would send the girl to mission home for care while 178(57.2\%) would render support to the girl to have the baby. Most parents
$260(84 \%)$ insist that the boy or man involved with the pregnancy, must accept the responsibility of caring for the girl.

Relationship between socio-demographic attributes of parents and their attitudes towards teenage pregnancy

Data on these attributes are presented in Tables 4-6.

\section{Descriptive statistics of attitude by age of respondent}

The mean, standard deviation, standard error, minimum and maximum value of attitude towards teenage pregnancy were computed for the different age groups of respondents. The results are given in Table 4.

Table 4: Descriptive statistics of attitude towards teenage pregnancy by age of respondents

\begin{tabular}{|l|l|l|l|l|l|l|}
\hline Group & N & Mean & $\begin{array}{l}\text { Standard } \\
\text { deviation }\end{array}$ & $\begin{array}{l}\text { Standard } \\
\text { Error }\end{array}$ & Min & Max \\
\hline 35-39yrs. & 86 & 26.79 & 6.33 & .683 & 12.00 & 40.00 \\
40-44yrs. & 69 & 27.81 & 5.39 & .649 & 17.00 & 40.00 \\
45-49yrs. & 39 & 25.51 & 5.70 & .913 & 15.00 & 40.00 \\
50-54yrs. & 30 & 26.67 & 5.22 & .953 & 16.00 & 37.00 \\
$55-59 y r s$. & 50 & 25.74 & 5.70 & .806 & 14.00 & 39.00 \\
60-64yrs. & 27 & 25.33 & 4.80 & .923 & 16.00 & 36.00 \\
65 \& above & 8 & 25.62 & 3.78 & 1.335 & 21.00 & 31.00 \\
Total & 309 & 26.52 & 5.68 & .323 & 12.00 & 40.00 \\
\hline
\end{tabular}

*All descriptive statistics were computed from parents' attitude scores towards teenage pregnancy. 


\begin{tabular}{|c|c|c|c|c|c|c|}
\hline Group & $\mathbf{N}$ & Mean & $\begin{array}{l}\text { Standard } \\
\text { deviation }\end{array}$ & $\begin{array}{l}\text { Standard } \\
\text { Error }\end{array}$ & Min & Max \\
\hline Christianity & 255 & 26.86 & 5.68 & .355 & 12.0 & 40.00 \\
\hline Muslim & 23 & 25.78 & 5.50 & 1.147 & 17.00 & 40.00 \\
\hline Traditional & 31 & 24.26 & 5.44 & .977 & 16.00 & 36.00 \\
\hline Total & 309 & 26.52 & 5.68 & .323 & 12.00 & 40.00 \\
\hline
\end{tabular}

*All descriptive statistics were computed from parents' attitude scores towards teenage pregnancy.

From Table 4, respondents in the age bracket 40-44 years had the highest mean attitude, (27.81) followed by those who are between 35 and 39 years (26.79) and the least were those in the age group 60-64 years (25.33). On the whole, values $(25.33-27.81)$ is so small that the differences due to age groups may not be significant.

From Table 5, Christians have the highest mean attitude towards teenage pregnancy (26.86) followed by Muslims (25.78) while the least in attitude were traditional religious respondents (24.26). The range of the mean values is fairly large $(24.26-26.86)$. Given the small between groups degree of freedom, the difference in mean attitude may be significant.

\section{Descriptive statistics of attitude towards teenage pregnancy by religion}

The mean, standard deviation, standard error, minimum and maximum of attitude towards teenage pregnancy were computed by religion of respondents. Table 6 is a summary of the results.

Table 6: Descriptive statistics of attitude towards teenage pregnancy by parents' level of education

\begin{tabular}{lllllll}
\hline Group & N & Mean & $\begin{array}{l}\text { Standard } \\
\text { deviation }\end{array}$ & $\begin{array}{l}\text { Standard } \\
\text { Error }\end{array}$ & Min & Max \\
\hline Primary & 69 & 25.70 & 5.15 & .620 & 16.00 & 40.00 \\
Secondary & 142 & 25.94 & 5.69 & .477 & 12.00 & 40.00 \\
Tertiary & 98 & 27.93 & 5.81 & .586 & 16.00 & 40.00 \\
Total & 309 & 26.52 & 5.68 & .323 & 12.00 & 40.00 \\
\hline
\end{tabular}

*All descriptive statistics were computed from parents' attitude scores towards teenage pregnancy.

From Table 6, those who were educated up to tertiary level have the highest mean attitude towards teenage pregnancy (27.93) followed by those educated to secondary while the least are those who had just primary education. This suggests that as the level of education goes up, mean attitude towards teenage pregnancy also increases. The effect of level of education may be significant.

\section{Descriptive statistics of attitude by respondents level of education}

The mean, standard deviation, standard error, minimum and maximum of attitude towards teenage pregnancy were computed by respondents' level of education. The results are given in Table 6.

\section{Result for research hypothesis}

This hypothesis stated that there is no significant relationship between socio-demographic attributes of parents (sex, age, religion, and level of education) and their attitude towards teenage pregnancy. This hypothesis was tested under the four socio-demographic attributes.

To test this hypothesis, Pearson product moment correlation was applied. The results are presented in table 7.

\section{Gender/sex}

To test for the significance of the effect of gender, the mean and standard deviation of attitude towards teenage pregnancy were computed for males and females.

Table 7: Independent t-test for gender based differences in attitude towards teenage

\begin{tabular}{|c|c|c|c|c|c|c|c|c|}
\hline Group & $\mathbf{N}$ & Mean & SD & SE & MD & $\mathbf{t}$ & Df & $\mathbf{P}$ \\
\hline Male & 117 & 24.85 & 5.74 & .530 & 2.68 & $4.1120^{*}$ & 307 & .000 \\
\hline Female & 192 & 27.53 & 5.41 & .391 & & & & \\
\hline Total & 309 & 26.52 & 5.68 & .323 & & & & \\
\hline
\end{tabular}

All descriptive statistics were computed from parents' attitude scores towards teenage pregnancy. 


\begin{tabular}{llllll}
\multicolumn{5}{c}{ Table 8: One-way ANOVA of attitude towards teenage pregnancy by ages of parent } \\
\hline \multicolumn{1}{c}{ Source of variation } & SS & df & MS & F & P \\
\hline Age of parents & 236.464 & 6 & 39.411 & 1.227 & .292 \\
Error & 9702.689 & 302 & 32.128 & & \\
Total & 9939.152 & 308 & & & \\
\hline
\end{tabular}

*All descriptive statistics were computed from parents' attitude scores towards teenage pregnancy.

From Table 7, the p-value (.000) associated with the computed t-value (4.120) is less than the chosen level of significance. In this case, the null hypothesis was rejected. This means that male and female parents differ significantly in their attitude towards teenage pregnancy.

From Table 8, the p-value (.292) associated with the computed f-value (1.227) is greater than .05 . The null hypothesis in this case was not rejected. This means that age of parent has no significant relationship with their attitude towards teenage pregnancy.

\section{Parents' age:}

To test for the significance of the effect of parents' age on attitude towards teenage pregnancy, one-way analysis of variance was applied. This involves the computation of sums of squares, mean squares and Fratio. The results are given in Table 8 .

\section{Parents' religion:}

To test the hypothesis for the effect of religion on parents' attitude towards teenage pregnancy, one-way ANOVA was done. The results are as presented in Table

Table 9: One-way ANOVA of attitude towards teenage pregnancy by religion of parents

\begin{tabular}{llllll}
\hline \multicolumn{1}{c}{ Source of variation } & SS & df & MS & F & P \\
\hline Parents' religion & 200.386 & 2 & 100.193 & $3.148^{*}$ & .044 \\
Error & 9738.766 & 306 & 31.826 & & \\
Total & 9939.152 & 308 & & & \\
\hline & *significant at .05 level. P = 0.44 M .05.
\end{tabular}

All descriptive statistics were computed from parents' attitude scores towards teenage pregnancy.

Table 10: Multiple pairwise comparison of attitude towards teenage pregnancy by religion of parents

\begin{tabular}{llll}
\hline Group & Christianity & Muslims & Traditional \\
\hline Christianity & 26.859 & 1.076 & $2.601^{*}$ \\
Muslims & .382 & 25.783 & 1.525 \\
Traditional & .016 & .327 & 24.258 \\
\hline \multicolumn{4}{c}{}
\end{tabular}

*values along main diagonal are group means, above are mean differences and below are $p$-values

All descriptive statistics were computed from parents' attitude scores towards teenage pregnancy.

From Table 9, the p-value (.044) associated with the computed f-value (3.148) is less than the chosen level of significance. Consequently, the null hypothesis was rejected. This means that parents' religion has a significant effect on their attitude towards teenage pregnancy.

Table 11: One-way ANOVA of attitude towards teenage pregnancy by parents' educational level

\begin{tabular}{llllll}
\hline Source of variation & SS & df & MS & F & P \\
\hline Level of education & 288.494 & 2 & 144.247 & $4.574^{*}$ & .011 \\
Error & 9650.658 & 306 & 31.538 & & \\
Total & 9939.152 & 308 & & & \\
\hline
\end{tabular}

*All descriptive statistics were computed from parents' attitude scores towards teenage pregnancy.

From Table 11, the p-value (.011) associated with the computed f-value (4.574) is less than the chosen level of significance (.05). As a result, the null hypothesis was rejected. This means that there is a significant relationship between parents' level of education and their attitude towards teenage pregnancy.

\section{DISCUSSION}

Perception of parents on teenage pregnancy

Most of the parents claimed that any teenage girl who is pregnant while not married is a social deviant and that such has no future. Also, that teenage 
pregnancy has a devastating effect on the girls' parents; it is a sign of parental failure in their responsibilities towards the girl child as well as a stigma to the girl and her family. These findings corroborate those of some other authors (Fernandes et al. 2012; Peteu 2011). Teenage pregnancy has also been described by some parents in this study as an ugly consequence of Western education. This view is supported by some other authors (Fernandes et al., 2012; Health Direct, (2012). On the contrary, Ekefre, Ekanem and Esien (2014), described education as a veritable tool towards curbing teenage pregnancy because it is a source of knowledge to ward off ignorance that might promote a lifestyle that is inimical to adolescent reproductive wellbeing. It has also been remarked that changing cultures due to urbanisation, globalisation, media influence including the internet as well as breakdown of traditional mechanisms for coping with and regulating adolescents' sexuality and norms of chastity before marriage are predisposing factors to early sexual debut in adolescents (Ekefre et al., 2014; FMOH, 2005). Some authors observed a link between teenage pregnancy and early sexualisation of female adolescents (Goicolea, Wulff, Ohman \& Sebastian, 2009).

Following the perception of parents on teenage pregnancy, their attitudes or reaction to this situation is subsequently presented.

\section{Attitude of parents towards teenage pregnancy}

Many parents react in various ways towards teenage pregnancy. In this study, the reactions included sending the girl away from home in anger and stopping her from continuing in school. These findings support those of Fernandes et al. (2012), which state that some fathers send their teenage pregnant daughters away and broke contact with them. Critically analysing this stance of some fathers, it appears to portray a negative reaction to an already bad situation as this may plunge the girl into further psychological trauma. Additionally, the socio-economic circumstances of the girl could become worse which might result in poor nutrition, inadequate health care with high probability of developing maternal complication(s) with eventual maternal mortality. The teenage girl is already disadvantaged socio-economically because of dependence on parents or guardians for subsistence. This scenario may further be aggravated if the man or boy responsible for the pregnancy does not have a means of livelihood and cannot provide for her. WHO (2014) states that adolescent pregnancy is the major contributor to maternal and child mortality and the vicious cycle of ill-health and poverty.

Sending the girl away, may likely expose her to wrong counsel and unsafe abortion. Statistics show that globally, about three million adolescents aged $15-19$ years undergo unsafe abortion every year (WHO, 2014). However, most parents in this study stated that they would rather support the girl to have the baby and go back to school thereafter. This position was supported by Mpaza (2006) who found that some parents send back their daughters to school after child birth.
Association of parental socio-demographic characteristics with teenage pregnancy

It was found that gender/sex had influence on parents' attitudes towards teenage pregnancy. Thus males and females differ significantly in their attitude towards teenage pregnancy. This difference may be that women are more tolerance and sympathetic, have more understanding than males since they know what pregnancy entails and the pains involved making them to react differently from men. This is in agreement with Fernandes et al. (2012) in the study that motherdaughter relationship during the adolescent pregnancy was reported as normal and good for the majority of mothers. Many of the mothers said they conversed a lot with their daughters, trying to support and accompany them during this new phase.

\section{Parental religion}

Parental religion has been found in this study to be significantly associated with the attitude of parents towards teenage pregnancy. Religion can be used as a regulatory moral mechanism over human beings, especially adolescents. This is supported by Assimeng, (2010) who stated that religion is a powerful social force and provides a moral framework for socialization.

\section{Level of education on the attitude of parents towards teenage pregnancy \\ In this study, it was found that parental} education influenced attitude towards teenage pregnancy. This is because education broadens people understanding and reasoning unlike less educated individual with shallow understanding and reasoning. This is supported by Mpaza (2006) who also found that education has a positive influence on one's attitude. In her study, educated parents sent their teenage daughters back to school after giving birth while parents with less education maintained that teenage mothers should remain at home.

\section{CONCLUSION}

Teenage pregnancy is an important public health concern that requires parents, government and other relevant agencies to collaborate in the effort to prevent its occurrence. This study shows that there are gaps in parental perception and attitudes towards teenage pregnant girls.

Therefore, it is recommended that parents should reappraise and strengthen their obligations towards their children particularly the adolescent/teenage daughters to enable them achieve their full potentials through prevention of teenage pregnancies.

\section{Further Recommendation}

1. Teenage pregnancy is one reason females do not realise their full potentials, therefore, parents should make use of resources within their disposal to support the girl child to prevent its occurrence. 
2. Parents should create a home environment that fosters communication, understanding and support towards their daughters to ensure the inculcation of moral values to prevent coerced sex, thus reduce teenage pregnancy.

3. Sexuality education should be undertaken at both family and formal schools level to create good knowledge of the structure and functions of the girls' reproductive system.

4. In the advent of teenage pregnancy, parents should try to be accommodating to help their daughters go through the crises situation successfully and thereafter, support them to achieve their full potentials.

\section{REFERENCES}

Assimeng, M., 2010. Religion and social change in West Africa. ( $2^{\text {nd }}$ ed.). Accra: Woelipubl. Services.

Coster, D., 2015. Discovering your teenage daughter is pregnant: Ten tips for parents. Blog retrieved from psychcentral.com/blog/achives/2013/06/24/ discovering-your-teenage-daughter-is-pregnant. (Retrieved 7/9/2014).

Ekefre, E. N., Ekanem, S. A and Esien, O. E., 2014. Teenage pregnancy and education in Nigeria: A Philo-Socialogical Management Strategy. Journal of Educational and Social Research, 4, (3): $41-47$.

Fernandes, A. O., Santos, H. P. O and Gualda, D. M. R., 2012. Adolescent pregnancy: Perception of mothers of young pregnant women. Acta Paul emterm, 25(1) http//dx doi/org/10./590/SO/03-2100201 0000100010.

FMOH., 2005. Family Planning Training for Physicians and Nursr/Midwives. National Training Manual. Abuja: Federal Ministry of Health, Nigeria.

Gilbert, N. J., 2011. Puerto Rican Teens perception of teen pregnancy and births in Holyoke, Massachusetts. A PhD Dissertation, University of Massachusetts, Amherst, USA. Retrieved from scholarworks.umass.edu/cgi/viewcontent.c gi?article=1371\&context. (Retrieved 8/9/2014).

Goicolea, I., Wulff, M., Ohman, A and San Sebastian, M., 2009. Risk factors for pregnancy among adolescent girls in Ecuador's Amazon Basin: A case-control study. Rev Panam Salud Publica, 26, (3): 221-8.

Health Direct., 2012. Teenage pregnancy: Pregnancy Birth and Baby. Retrieved from http://www pregnancy birthbaby.org.au.teenage pregnancy

Inter Press Service., 2011. Teen Pregnancy Bucks Global Downward. Retrieved from http://ipsnews.net/news.asp?idnews=36729. (Retrieved 11/6/ 2012).
Marnach, E. F., Forrest, J. D and Goldman, N., 2013. Teenage pregnancy in industrialized countries. New Haven Connecticut: Yale University Press.

Meddinus, U. V and Johnson, T. C., 2007. Factors associated with unwanted pregnancy Retrieved from http://www.Pregnancy.org. (Retrieved 15/7/2014).

Miller B. C., 2006. Family influences on adolescent sexual and contraceptive behaviour. Journal of sex research, 39, (17): 2.

Mitchel, J., 2007. Sexual Matters and peers. Retrieved from http:/www. Health all refers.com. (Retrieved 15/7/ 2014)

Mpanza, N. D., 2006. Educators' Attitude towards Teenage Pregnancy. A Master's Dissertation, University of Zululand, South Africa. Retrieved from uzulu.ac.za (Retrieved 8/10/2014).

Nava, M., 2012. Parent's perception of teenage pregnancy. A PhD Dissertation, Loyola University of Chicago. Retrieved from ecommons.luc.edu/cgi/viewcontent.cgi?article=1 369\&context=luc (Retrieved 7/9/2014).

National Population Commission (Nigeria) \& ICF International., 2008. Nigeria Demographic Health Survey. Abuja, Nigeria \& Rockville, Maryland, USA.

National Population Commission (Nigeria) \& ICF International., 2014. Nigeria Demographic Health Survey. Abuja, Nigeria \& Rockville, Maryland, USA.

National Population Commission Census., 2014. Cross River State Census Results.

Peteu, O., Eriksen, A and Swanson, V., 2011. Perspectives on teenage pregnancy in Dundee: A qualitative study. Directorate of Public Health, King's Cross Hospitals, Dundee, NHS, Tayside. Retrieved from www.sexualhealthtayside.org/cm s/subsection/executive summary. (Retrieved 8/10/2014).

Salaman, M., 2010. Teen pregnancy: a winnable Public Health Battle? Livescience (Retrieved from www.livescience.com/10177-teen-winnablepublic-health-battle.html.)

Silk, J and Romero, D., 2014. The role of parents and families in teen pregnancy prevention. An analysis of programs and policies. Journal of Family Issues. 35, (10): 1339-1362.

Spencer, S., 2011. The eHow: Facts about Teenage pregnancy. Retrieved from http://www.ehow.com/about 4619346 teen. (Retrieved 8/10/2014). 
Telford, L., 2013. Teenage girls at risk of suicide if pregnant. Irish News. www.independent.ie/irishnews/teenage-girls-at-risk-of-suicide-ifpregnant-psychiatrist-28955845.html.

WHO., 2007. Adolescent pregnancy - Unmet needs and undone deeds. A review of literature and programmes. Department of Child and Adolescent Health and Development. Geneva: Switzerland.
WHO., 2014. Adolescent pregnancy. WHO Fact Sheet. Geneva: Switzerland.

Yamane, T., 1967. Sample size calculation. http://www.medscape.com/article 